\title{
Influence of Slope and Management Practices on Top-Soils Fertility Status of Compound Farms in Nsukka Campus
}

\author{
Benedict Odinaka Okorie ${ }^{1 *}$, Niraj Yadav ${ }^{2}$, Charles LA Asadu ${ }^{1}$, Muhammad Tariq ${ }^{3}$, Imran Ahmed ${ }^{4}$ and Umeugok- \\ we C Pascal ${ }^{1}$ \\ ${ }^{1}$ Department of Soil Science, University of Nigeria, Nsukka, Nigeria \\ ${ }^{2}$ Department of Irrigation and Plant Environment, French Associates Institute for Agriculture and Biotechnology for Drylands, Jacob \\ Blaustein Institutes for Desert Research, Ben Gurion University of the Negev, Israel \\ ${ }^{3}$ Department of Soil and Environmental Sciences, The Agriculture University of Peshawar, Pakistan. \\ ${ }^{4}$ Directorate of Technical Cooperation in Africa, Abuja, Nigeria \\ *Corresponding Author: Benedict Odinaka Okorie, Department of Soil Science, University of Nigeria, Nsukka, Nigeria.
}

Received: December 21, 2021; Published: December 30, 2021

\begin{abstract}
The study was carried out to assess the influence of slope and management practices on top-soils fertility status of compound farms in the University of Nigeria Nsukka (UNN) campus, Enugu state Nigeria. Top soil samples (0-20 cm depth) were collected from twenty compound farms, ten each from the upper slopes compound farms (USCFs) in Ikejiani and Ezenwaeze streets and lower slopes compound farms (LSCFs) at Mbanefo Street. The elevation of the USCFs ranged from 458 to $447 \mathrm{~m}$ while LSCFs ranged from 415 to $423 \mathrm{~m}$ above the mean sea level (amsl). The soil samples were analyzed in the UNN Department of Soil Science Laboratory. The results showed that slopes and management practices influenced top-soils fertility status of compound farms. Slopes affected soil fertility parameters such as organic matter content, total nitrogen, exchangeable calcium, cation exchange capacity, and effective cation exchange capacity. The upper slope compound farms were more fertile relative to the lower slopes compound farms. The combined application of organic and inorganic manures had a greater effect on soil fertility status compared to a single application of organic or inorganic fertilizer. The combined application of organic and inorganic fertilizers should be adopted to enhance soil fertility status of compound farms in both slopes.
\end{abstract}

Keywords: Compound farms; Management Practices; Slopes; Soil Fertility

\section{Introduction}

Soil fertility is the status of the soil with respect to its capacity to supply nutrients to plants in adequate and suitable amounts. Nigerian soils are generally low in fertility as a result of their origin. Poor management practices employed by farmers further depreciate soil fertility through harvesting, leaching and soil erosion. In order to maintain soil fertility, farmers have to take note of the characteristics and constraints of their soils and use sustainable management practices to conserve and improve fertility. Slope is one of such characteristics of farmland that farmers have to take into consideration. Though slope is an inherent geographic condition of lands that is beyond the control of farmers. However, through management practices, farmers can manage their farmlands for greater crop productivity. Management practices refer to techniques and methods employed by farmers to maintain and improve the overall soil fertility. Farmers deliberately incorporate household refuse, crop residues, animal manures and inorganic fertilizer into compound farm soils with the sole purpose of improving soil fertility so as to enhance crop productivity. Compound farm can be defined as a 
gardening system of cultivating crops and rearing livestock on fragmented lands within the confines of homesteads where by wastes from the house, residues from crops, and droppings from animals reared are added back to the soil to enhance fertility. These additions buffer the effect of nutrients lost through harvesting, leaching and runoff as a result of slope positions. Slope positions influence the movement of nutrients and water within the soil thereby affecting soil fertility status at any given time. Mulugeta et al. (2012) [31] noted that slope accelerates soil disturbance through erosion and affects soil properties by shaping the patterns of crop production, litter production, and decomposition, with resultant effects on carbon and nitrogen contents of the soils. Slopes therefore have marked influence on soil properties (Amuyou and Kotingo, 2015) [3], such that fertility and physical properties of soils differ across slope gradients (Awdenegest and Nicholas, 2008) [8]. The influence of slope on soil properties has been widely discussed by Noma et al. (2005) [33]; Essoka and Jaieyeoba (2008); Ogunwale et al. (2002) [34]; Babalola et al. (2007) [9]; Farmanullah et al. (2013) [19] and Amuyou and Kotingo (2015) [3]. The relationship between soil fertility and slope positions varies depending on inherent soil properties, vegetation cover, weathering, leaching, erosion, among others. Generally, organic materials and nutrients tend to be transported from upper slopes and deposited at lower slopes.

Therefore, slope not only influences soil properties but also determines farmers' choice of management practices for effective maintenance of the fertility of soils. Since the removed nutrients from the soil have to be adequately replaced, sustainable management practices are employed to minimize nutrient losses, improve the overall soil fertility and increase crop yield. However, not much is known of the influences of slope and management practices on the fertility status of compound farms in Nsukka. Thus, this research assesses the influence of slope and management practices on top-soils fertility status of compound farms in the University of Nigeria Nsukka (UNN) campus.

\section{Materials and Methods \\ Study Location}

The study was carried out at the University of Nigeria Nsukka campus, situated approximately by latitude $6^{\circ} 54^{\prime} \mathrm{N}$ and longitude $7^{\circ} 24^{\prime} \mathrm{E}$ within the derived savanna zone of eastern Nigeria with an altitude of $447.26 \mathrm{~m}$ above sea level (Oko-Ibom and Asiegbu, 2006) [37]. The area is characterized by a humid tropical climate with wet (April- October) and dry (November-March) seasons, and a mean annual rainfall of $1750 \mathrm{~mm}$ bimodally distributed with peaks in July and September; mean annual maximum (day) and minimum (night) temperatures of $31^{\circ} \mathrm{C}$ and $21^{\circ} \mathrm{C}$ respectively (UNN Meteorological Station, 2010) [44]. Relative humidity ranges between 70 to 80\% (Oko-Ibom and Asiegbu, 2006) [37] and falls below 60\% during the period of Harmattan- a short period of about three weeks of hazy and very dry weather usually from December through January (Asadu et al., 2001) [6].

The altitude of the compound farms sampled ranged from 415 to $458 \mathrm{~m}$ above mean sea level (amsl) and was divided into two topographic positions; upper slopes compound farms (USCFs)and lower slopes compound farms (LSCFs). Upper slopes ranged from 458 to $447 \mathrm{~m}$ while LSCFs ranged from 415 to $423 \mathrm{~m}$ amsl. The road that cuts across UNN's main gate through St Peter's Catholic Church to Medical Centre bordering school premises and staff quarters demarcated the upper slopes from the lower slopes. A handheld Global Positioning System (GPS receiver) was used to identify the geographical locations of the compound farms sampled in both slope positions as shown in Table 1. Topsoil samples (0-20 cm depth) were collected from representative upper slope compounds at Ikejiani Street and Ezenwaeze Street; and lower slope at Mbanefo Street of UNN during February 2019 (Table 1). The random method based on the variability of the land was used to collect soil samples from the selected compound farms using soil auger. Twenty soil samples were collected in all, ten from the upper and ten from the lower slopes. A structured questionnaire was used to obtain information on management practices adopted by the compound farmers across the slopes. Farmers provided information on the farming practices such as organic manure and inorganic fertilizer applications, supplemental irrigation and cropping systems (Table 1). 
Influence of Slope and Management Practices on Top-Soils Fertility Status of Compound Farms in Nsukka Campus

\begin{tabular}{|c|c|c|c|c|}
\hline Compound Farm & Altitude (m amsl) & Latitude (N) & Longitude (E) & Management Practices \\
\hline \multicolumn{5}{|c|}{ Upper Slopes Compound Farms } \\
\hline 4 Ezenwaeze street & 451 & $\mathrm{~N} 6^{\circ} 51.493^{\prime}$ & $\mathrm{E}^{\circ} 24.472^{\prime}$ & Organic, Not irrigated \\
\hline 7 Ezenwaeze street & 453 & N6 $6^{\circ} 1.493^{\prime}$ & $\mathrm{E}^{\circ} 24.534^{\prime}$ & Organic, irrigated \\
\hline 11 Ezenwaeze street & 453 & $N 6^{\circ} 51.475^{\prime}$ & $\mathrm{E}^{\circ} 24.529^{\prime}$ & BIO, Not irrigated \\
\hline 236 Ikejiani street & 449 & $\mathrm{~N} 6^{\circ} 51.490^{\prime}$ & $\mathrm{E}^{\circ} 24.403^{\prime}$ & BIO, irrigated \\
\hline 238 Ikejiani street & 447 & $N 6^{\circ} 51.523^{\prime}$ & $\mathrm{E} 7^{\circ} 24.465^{\prime}$ & Organic, Not irrigated \\
\hline 239 Ikejiani street & 447 & $N 6^{\circ} 51.527^{\prime}$ & $\mathrm{E} 7^{\circ} 24.438^{\prime}$ & Organic, irrigated \\
\hline 241 Ikejiani street & 447 & $N 6^{\circ} 51.536^{\prime}$ & $\mathrm{E} 7^{\circ} 24.450^{\prime}$ & BIO, Not irrigated \\
\hline 243 Ikejiani street & 449 & $N 6^{\circ} 51.518^{\prime}$ & $\mathrm{E}^{\circ} 24.530^{\prime}$ & BIO, irrigated \\
\hline 248 Ikejiani street & 455 & $N 6^{\circ} 51.487^{\prime}$ & $\mathrm{E} 7^{\circ} 24.607^{\prime}$ & Organic, Not irrigate \\
\hline 250 Ikejiani street & 458 & $N 6^{\circ} 51.469^{\prime}$ & $\mathrm{E}^{\circ} 24.617^{\prime}$ & Organic, irrigated \\
\hline \multicolumn{5}{|c|}{ Lower Slopes Compound Farms } \\
\hline 4 Mbanefo street & 415 & $N 6^{\circ} 52.236^{\prime}$ & $\mathrm{E} 7^{\circ} 24.748^{\prime}$ & BIO, Not irrigated \\
\hline 7 Mbanefo street & 417 & $N 6^{\circ} 52.217^{\prime}$ & $\mathrm{E} 7^{\circ} 24.786^{\prime}$ & BIO, irrigated \\
\hline 8 Mbanefo street & 418 & $\mathrm{~N}^{\circ} 52.243^{\prime}$ & $E 7^{\circ} 24.800^{\prime}$ & Organic, Not irrigated \\
\hline 10 Mbanefo street & 417 & $N 6^{\circ} 52.258^{\prime}$ & $\mathrm{E}^{\circ} 24.835^{\prime}$ & Organic, irrigated \\
\hline 12 Mbanefo street & 419 & $N 6^{\circ} 52.256^{\prime}$ & $\mathrm{E}^{\circ} 24.853^{\prime}$ & BIO, Not irrigated \\
\hline 15 Mbanefo street & 420 & $N 6^{\circ} 52.200^{\prime}$ & $\mathrm{E} 7^{\circ} 24.888^{\prime}$ & BIO, irrigated \\
\hline 16 Mbanefo street & 419 & $N 6^{\circ} 52.245^{\prime}$ & $\mathrm{E} 7^{\circ} 24.887^{\prime}$ & Organic, irrigated \\
\hline 17 Mbanefo street & 423 & $N 6^{\circ} 52.201^{\prime}$ & $\mathrm{E}^{\circ} 24.930^{\prime}$ & Organic, Not irrigated \\
\hline 19 Mbanefo street & 421 & $N 6^{\circ} 52.232^{\prime}$ & $\mathrm{E}^{\circ} 24.939^{\prime}$ & BIO, Not irrigated \\
\hline 20 Mbanefo street & 423 & $N 6^{\circ} 52.257^{\prime}$ & $\mathrm{E}^{\circ} 24.944^{\prime}$ & BIO, Irrigated \\
\hline
\end{tabular}

BIO: both organic and inorganic fertilizer

Table 1: Sampling locations and site characteristics.

\section{Laboratory Analysis}

All the sampled soils were bagged in fresh clean polythene bags and were prepared for analyses in the laboratory by air drying and sieving using a $2 \mathrm{~mm}$ sieve. The samples were analyzed for particle size distribution, soil pH, organic carbon, total nitrogen, available phosphorus, exchangeable acidity, and exchangeable calcium, magnesium, potassium, and sodium. Laboratory analyses were conducted at the Department of Soil Science University of Nigeria, Nsukka using the following standard methods. Soil particle size distribution was determined by the Bouycuous hydrometer method (Gee and Or, 2002) [21]. Soil pH was measured in both water and $0.1 \mathrm{~N} \mathrm{KCl}$ at the soil-liquid ratio of 1:2.5. Soil organic carbon was determined by the Walkley and Black wet digestion method (Nelson and Sommers, 1982) [32]. Total nitrogen was determined by the micro Kjedahl digestion method (Bremner and Mulvaney, 1982) [10]. Available phosphorus was determined by the Bray II method (Olsen and Sommers, 1982) [39]. Exchangeable calcium and magnesium were determined by ETDA titration while exchangeable potassium and sodium were determined by flame photometry (Jackson, 1962) [24]. Exchangeable acidity was determined by the titration method (Mclean, 1982) [29]. Effective Cation Exchange Capacity (ECEC) was obtained by the summation of all exchangeable cations. Base saturation was calculated as a percentage of the value of the summation of exchangeable bases over cation exchange capacity.

\section{$\mathrm{PBS}=\sum \mathrm{EB} / \mathrm{CEC} \times 100$}

Where $\sum E B=$ Summation of the exchangeable bases. 


\section{Statistical Analysis}

The data generated from the laboratory analysis were subjected to two-way analysis of variation (ANOVA) using GenStat Discovery Edition 2. Slope (location) positions and management practices were considered as main factors. The mean comparison was done using fisher's least significant difference (LSD) test at $\mathrm{P}<0.05$ significant level.

\section{Results and Discussions}

\section{Effects of Slope and Management Practices on Soil Particle Size Distribution}

The result showed that the effect of slope on particle size distribution in both slopes was significant whereas the effect on management practices was not significant (Table 2). However, the interaction of slope and management practices significantly influenced particle size distribution (Table 3). The values of sand, silt, and clay varied from 818.00-902.00 g kg-1; 40.00-72.00 g kg-1 and 62.00$110.00 \mathrm{~g} \mathrm{~kg}^{-1}$ respectively in both the LSCFs and USCFs. Comparison at slope level revealed that sand fraction was significantly greater in the LSCFs relative to the USCFs at ( $\mathrm{p} \leq 0.05$ ). The quartz-rich parent material upon which the soils are formed could be responsible for the high values in the lower slope. The removal, transport, and re-deposition of sand particles by erosion could have also influenced the higher sand fraction at the lower slope relative to the upper slope. The silt and clay contents of the USCFs were higher than that of LSCFs due to their low mobility down the slope. Low silt content is an indication of highly weathered soils (Ahn, 1993) [1] implying that the lower slope soils are at an advanced stage of weathering compare to upper slope soils.

\begin{tabular}{|l|c|c|c|}
\hline Slope & \% Clay & \% Silt & \% Total Sand \\
\hline Lower slope & 6.20 & 4.00 & 90.2 \\
\hline Upper slope & 11.0 & 7.20 & 81.8 \\
\hline F-LSD $_{(0.05)}$ & 2.78 & 2.53 & 4.75 \\
\hline
\end{tabular}

F-LSD ${ }_{(0.05)}$ : Fisher's Least Significant Difference at 5\% probability, NS: Not significant

Table 2: Effects of Slope on Soil Particle Size Distribution.

\begin{tabular}{|l|l|c|c|c|}
\hline Management practice & Slope & \% Clay & \% Silt & \% Total Sand \\
\hline Fertilization & Lower & & & \\
\hline & Organic and inorganic & 7.00 & 5.00 & 88.0 \\
\hline & Organic & 5.40 & 3.00 & 92.4 \\
\hline & Upper & & & \\
\hline & Organic and inorganic & 9.80 & 6.60 & 83.6 \\
\hline F-LSD \\
\hline Irrigation & Organic & 12.20 & 7.80 & 80.0 \\
\hline & & 3.93 & 3.57 & 6.71 \\
\hline & Lower & & & \\
\hline & Irrigated & 6.87 & 4.00 & 89.2 \\
\hline & Non irrigated & 5.53 & 4.00 & 91.2 \\
\hline & Upper & & & \\
\hline & Irrigated & 10.83 & 7.95 & 81.2 \\
\hline F-LSD & Not Irrigated & 11.17 & 6.45 & 82.4 \\
\hline & & 3.67 & 3.61 & 6.78 \\
\hline
\end{tabular}

Table 3: Interaction Effects of Slope and Management Practices on Soil Particle Size Distribution. 
Effects of Slope Positions and Management Practices on Soil Fertility Properties

The interaction of slope and management practices significantly influenced soil fertility status of the compound farm soils. Management practices alone had no significant effect on soil fertility properties. However, slope significantly influenced OM, TN, Ca, CEC, ECEC and BS. Whereas pH, Mg, K, Na, EA and Av. P were not affected. The pH values in $\mathrm{H}_{2} 0$ ranged from 6.74 to 6.32 in the USCFs and LSCFs respectively and were rated neutral to slightly acid by Enwezor et al. (1989) [13]. The higher value of USCFs pH (6.74 for pH in $\mathrm{H}_{2} \mathrm{O}$ ) compared with the LSCFs (6.32) can be attributed to higher vegetation cover as well as a lower rate of mineralization of organic material at the upper slope, hence the accumulation of more organic matter content which enhances soil pH. Similarly, Amuyou and Kotingo (2015) [3] reported that soil pH value was relatively high in the upper slope segment compared to other segments of the catena attributed to grasses which covered the upper slope. Ogunwale et al. (2002) [34] and Babalola et al. (2007) [9] also reported a decrease in pH down the slope. Contrariwise, Hendershot et al. (1992) [22] reported a slightly higher pH at the down slope positions. However, the main effect of slope and the interaction effect of slope and management practices on soil $\mathrm{pH}\left(\mathrm{H}_{2} \mathrm{O}\right)$ were not significant across the compound farms.

The value of organic matter was found to be higher at the USCFs $\left(30.2 \mathrm{~g} \mathrm{~kg}^{-1}\right)$ against $13.9 \mathrm{~g} \mathrm{~kg}^{-1}$ at the LSCFs. Generally, the OM content was rated moderate to high according to Enwezor et al. (1989) [13]. The higher value of organic matter at the upper slope (30.2 $\mathrm{g} \mathrm{kg}^{-1}$ ) relative to the lower slope $\left(13.9 \mathrm{~g} \mathrm{~kg}^{-1}\right)$ could be due to higher vegetation density leading to higher accumulation of organic materials in the upper slopes compound farms. Contrariwise, Farmanullah et al. (2013) [19] reported that organic matter was higher at lower slopes relative to upper slopes.

Total nitrogen varied from $\left(0.9 \mathrm{~g} \mathrm{~kg}^{-1}\right)$ at the LSCFs to $1.6 \mathrm{~g} \mathrm{~kg}^{-1}$ at the USCFs and rated low to high respectively according to Enwezor et al. (1989) [13]. Nitrogen influences the decomposition of organic matter in the soil which ultimately leads to enhanced fertility (Essiet, 1990) [14]. This explains the higher value of total nitrogen and organic matter content at the upper slope relative to the lower slope. Noma et al. (2005) [33] reported that total N followed a similar trend as soil organic matter since organic nitrogen constitutes the bulk of total $\mathrm{N}$ in tropical soils. However, this contrasting result may be due to higher fertilization with nitrogen fertilizers at the lower slopes. Ezeaku and Iwuanyanwu (2013) [18] reported that the cultivation of soil exposes the soil organic matter to a greater rate of decay and oxidation resulting in a low amount of total nitrogen content of the soil.

Available phosphorus varied from 50.9-52.5 mg kg-1 in the USCFs relative to LSCFs. These values were rated high by Enwezor et al. (1989) [13]. High level of available phosphorus in both slopes may be attributed to intensive P fertilization. However, slightly lower values of $\mathrm{P}$ at the USCFs can be attributed to the high weather ability of the soils, higher clay content, leaching by high-intensity rainfall (Bubba et al., 2003) [11]. Similarly, Farmanullah et al. (2013) [19] reported that phosphorus was higher at lower slopes than top slopes. Mengel and Kirkby (1987) [30] reported that the availability of nitrogen improved the availability of phosphorus and vice versa, thus TN and available P were both higher at lower slope relative to the upper slope. Poor soil management practices and the nature of tropical soils account for heavy nutrient losses through soil erosion and nutrient leaching (Hossner and Juo, 1999) [23]. Moreover, with the intensification of cropping system, organic matter and $\mathrm{N}$ in the soils are readily depleted, while phosphorus and other nutrient reserves are slowly but steadily mined (Tanimu et al., 2013) [43].

Exchangeable acidity (EA) was significantly affected $(\mathrm{p} \leq 0.05)$ by the interaction of slope and management practices. The EA varied from $1.76 \mathrm{cmol} \mathrm{kg}^{-1}$ in the LSCFs to $1.48 \mathrm{cmol} \mathrm{kg}^{-1}$ in the USCFs with no significant difference between the means. These values of EA were rated low by Enwezor et al. (1989) [13]. This can be attributed to the pH values which were neutral to slightly acid. However, continuous cultivation leads to the acidification of soils (Aguilera et al., 2013) [43]. The EA values in these locations were made up of only hydrogen ions with trace amounts of aluminum ions. The higher EA value in the LSCFswas a result of the lower organic matter content of the soils resulting in lower exchangeable bases.

Exchangeable calcium varied significantly at $(\mathrm{p} \leq 0.05)$ from $3.44 \mathrm{cmol} \mathrm{kg}^{-1}$ in the USCFs to $1.78 \mathrm{cmol} \mathrm{kg}^{-1}$ in the LSCFs. These values

Citation: Benedict Odinaka Okorie., et al. "Influence of Slope and Management Practices on Top-Soils Fertility Status of Compound Farms in Nsukka Campus”. Medicon Agriculture \& Environmental Sciences 2.1 (2022): 25-33. 
of $\mathrm{Ca}^{2+}$ were rated low to moderate by Enwezor et al. (1989) [13]. Low values of $\mathrm{Ca}^{2+}$ at the LSCFs could be attributed to leaching losses by the high tropical rainfall as well as low content in the parent rock from which the soils were formed. Higher $\mathrm{Ca}^{2+}$ levels in the upper slopes could be due to the denser vegetation that hinders the impact of raindrops on soil surface thus decelerating runoff and leaching of nutrient elements down the slope. According to Essiet, (2001) [15] for any soil, its fertility would be determined by two compounds, clay, and organic matter. The low clay, silt and organic matter content of the LSCFs as well as unfavorable management practices might be responsible for the low values of $\mathrm{Ca}^{2+}$. Exchangeable magnesium was higher in the USCFs $\left(1.31 \mathrm{cmol} \mathrm{kg}^{-1}\right)$ compare to the LSCFs (1.14 $\mathrm{cmol} \mathrm{kg}^{-1}$ ) with no significant difference between the means. These values of $\mathrm{Mg}$ were rated high by Enwezor et al. (1989) [13]. The exchangeable Na varied from $0.17 \mathrm{cmol} \mathrm{kg}^{-1}$ in the USCFs to $0.18 \mathrm{cmol} \mathrm{kg}^{-1}$ in the LSCFs with no significant difference between the means. These values of exchangeable Na were rated moderate by Enwezor et al. (1989) [13]. Similarly, Garcia et al. (1990) [20] reported highest $\mathrm{Na}^{+}$concentration at bottom slope position in eroded sites relative to top sites. The exchangeable $\mathrm{K}$ varied from 0.49 $\mathrm{cmol} \mathrm{kg}^{-1}$ in the USCFs to $0.46 \mathrm{cmol} \mathrm{kg}^{-1}$ in the LSCFs with no significant difference between the means. These values of $\mathrm{K}_{\text {were }}$ rated high by Enwezor et al. (1989) [13]. Farmanullah et al. (2013) [19] reported higher values of K at lower slopes relative to top slopes. The higher values of exchangeable K in the USCFs compared to the LSCFs could be a result of combined fertilization with organic and inorganic fertilizers.

Slope had a significant effect on CEC of soils in the study area. Cation exchange capacity (CEC) is an overall assessment of the potential fertility of the soil and the values depend critically on soil pH (Kodiya, 1988) [25]. The CEC varied from $7.80 \mathrm{cmol} \mathrm{kg}^{-1}$ in the LSCFs to $13.88 \mathrm{cmol} \mathrm{kg}^{-1}$ at the USCFs. This value of CEC was rated low to moderate by Enwezor et al. (1989) [13]. According to Landon (1991), the higher the CEC, the more the soil fertility and the more productive the soil is. Low values of CEC may be attributed to low clay and humus contents as well as low pH values (Asadu et al., 1997) [5]. It has been reported that low to medium CEC value of tropical soils is due to the dominance of kaolinitic clays in the fine-earth fractions (Ojanuga and Awojuola, 1981) [35]. Most researchers have observed that the CEC of tropical soils is related to their organic matter content (Aluko and Oguntala, 1997 [2], Noma et al., 2005) [33]. Ludwig et al. (2001) [27] noted that soils with low CEC might have been subjected to leaching of nutrients like nitrogen, potassium and magnesium and hence lower yield potentials than those with higher CECs (Asadu et al., 1997) [5]. However, lower CEC levels at the LSCFs was due to low organic matter contents as well as the influence of soil texture and the type of clay minerals. Clayey soils were reported to have higher CEC than Sandy soils mainly due to charges resulting from isormorphous substitution (Rhoades, 1982) [40].

Effective cation exchange capacity (ECEC) and \% base saturation (BS) were significantly affected by slope positions. The ECEC was greater at the USCFs $\left(6.88 \mathrm{cmol} \mathrm{kg}^{-1}\right)$ relative to the LSCFs $\left(5.34 \mathrm{cmol} \mathrm{kg}^{-1}\right)$ and rated low to moderate respectively by Enwezor et al. (1989) [13]. Whereas the \% BS was rated high by Enwezor et al. (1989) [13] and was greater at the USCFs (77.40 \%) relative to the LSCFs $(68.80 \%)$.

\begin{tabular}{|c|c|c|c|c|c|c|c|c|c|c|c|c|c|}
\hline Slope & $p H$ & $O C$ & $O M$ & $T N$ & $\mathrm{Ca}$ & $M g$ & $\boldsymbol{K}$ & $N a$ & $E A$ & $A v . P$ & CEC & ECEC & $B S$ \\
\hline & $\mathrm{H}_{2} 0$ & & $\%$ & & \multicolumn{4}{|c|}{$\begin{array}{l}\text { Exchangeable bases } \\
\qquad \mathrm{cmol} \mathrm{kg}{ }^{-1}\end{array}$} & $\mathrm{cmol} \mathrm{kg}^{-1}$ & $\mathrm{mg} \mathrm{kg}^{-1}$ & \multicolumn{2}{|c|}{$\mathrm{cmol} \mathrm{kg}^{-1}$} & $\%$ \\
\hline Lower & 6.32 & 0.92 & 1.39 & 0.90 & 1.78 & 1.14 & 0.46 & 0.18 & 1.76 & 52.50 & 7.80 & 5.34 & 68.80 \\
\hline Upper & 6.74 & 1.75 & 3.02 & 0.16 & 3.44 & 1.31 & 0.49 & 0.17 & 1.48 & 50.90 & 13.88 & 6.88 & 77.40 \\
\hline F-LSD ${ }_{(0.05)}$ & NS & 0.24 & 0.42 & 0.05 & 0.69 & NS & NS & NS & NS & NS & 1.76 & 0.70 & 4.86 \\
\hline
\end{tabular}

Table 4: Effects of Slope on Selected Soil Fertility Properties. 


\begin{tabular}{|c|c|c|c|c|c|c|c|c|c|c|c|c|c|c|}
\hline \multirow[t]{2}{*}{$\begin{array}{l}\text { Management } \\
\text { Practice }\end{array}$} & \multirow[t]{2}{*}{ Slope } & $p H$ & $O C$ & $O M$ & $T N$ & $\mathrm{Ca}$ & $M g$ & $K$ & $N a$ & \multirow{3}{*}{$\begin{array}{c}\boldsymbol{E A} \\
\mathrm{cmol} \\
\mathrm{kg}^{-1} \\
\end{array}$} & \multirow{3}{*}{$\begin{array}{c}\text { AV. } P \\
\mathrm{mgkg}^{-1}\end{array}$} & \multirow{3}{*}{$\begin{array}{c}C E C \\
\text { cmol } \\
\mathrm{kg}^{-1} \\
\end{array}$} & \multirow{3}{*}{$\begin{array}{c}\text { ECEC } \\
\mathrm{cmol} \\
\mathrm{kg}^{-1} \\
\end{array}$} & \multirow{2}{*}{$\begin{array}{r}\text { BS } \\
\%\end{array}$} \\
\hline & & $\mathrm{H}_{2} \mathrm{O}$ & & $\%$ & & \multicolumn{4}{|c|}{$\begin{array}{c}\text { Exchangeable Bases } \\
\mathrm{cmol} \mathrm{kg}^{-1}\end{array}$} & & & & & \\
\hline \multirow[t]{6}{*}{ Fertilization } & Lower & & & & & & & & & & & & & \\
\hline & $\mathrm{BIO}$ & 6.32 & 1.04 & 1.79 & 0.08 & 2 & 1.22 & 0.47 & 0.17 & 1.64 & 57.5 & 7.6 & 5.54 & 70.2 \\
\hline & Organic & 6.32 & 0.8 & 1.39 & 0.09 & 1.56 & 1.06 & 0.45 & 0.2 & 1.88 & 47.6 & 8 & 5.14 & 63.4 \\
\hline & Upper & & & & & & & & & & & & & \\
\hline & $\mathrm{BIO}$ & 6.58 & 1.75 & 3 & 0.18 & 3.1 & 1.3 & 0.49 & 0.16 & 1.48 & 61.7 & 13.28 & 6.53 & 76 \\
\hline & Organic & 6.9 & 1.76 & 3.03 & 0.13 & 3.78 & 1.32 & 0.48 & 0.17 & 1.48 & 40.1 & 14.48 & 7.23 & 78.8 \\
\hline$F-L S D_{(0.05)}$ & & NS & 0.34 & 0.59 & 0.07 & 0.98 & NS & NS & NS & NS & NS & 2.49 & 0.99 & 6.88 \\
\hline \multirow[t]{6}{*}{ Irrigation } & Lower & & & & & & & & & & & & & \\
\hline & IRR & 6.28 & 0.88 & 1.52 & 0.09 & 1.92 & 1.08 & 0.42 & 0.19 & 1.91 & 57.4 & 7.55 & 5.57 & 65.3 \\
\hline & NIR & 6.36 & 0.97 & 1.66 & 0.08 & 1.64 & 1.2 & 0.5 & 0.17 & 1.61 & 47.6 & 8.05 & 5.11 & 68.3 \\
\hline & Upper & & & & & & & & & & & & & \\
\hline & IRR & 6.98 & 1.72 & 2.95 & 0.17 & 3.53 & 1.39 & 0.48 & 0.17 & 1.48 & 55.9 & 12.63 & 7.05 & 78.5 \\
\hline & NIR & 6.5 & 1.79 & 3.08 & 0.14 & 3.35 & 1.24 & 0.49 & 0.17 & 1.48 & 46 & 15.13 & 6.71 & 76.3 \\
\hline$F-L S D_{(0.05)}$ & & 0.62 & 0.35 & 0.6 & 0.07 & 0.99 & NS & NS & NS & NS & NS & NS & 1.01 & 6.95 \\
\hline
\end{tabular}

BIO: organic and inorganic fertilizer, IRR: Irrigated, NIR: Non-irrigated, NS: non-significant, OC: organic carbon, OM: organic matter, TN: Total Nitrogen, Ca: Calcium, Mg: Magnesium, K: Potassium, Na: Sodium, EA: Exchangeable Acidity, Av. P: Available Phosphorus, CEC: Cation exchange capacity, ECEC: effective cation exchange capacity, BS: percentage base saturation, F-LSD ${ }_{(0.05)}$ : Fisher's Least Significant Difference at $5 \%$ probability

Table 5: Interaction Effects of Slope and Management Practices on Soil Chemical Properties.

\section{Conclusions}

The study was carried out to assess the influence of slope and management practices on top-soils fertility status of compound farms in the University of Nigeria Nsukka (UNN) campus, Enugu state Nigeria. From the findings, slopes affect soil fertility parameters such as organic matter content, total nitrogen, exchangeable calcium, cation exchange capacity, and effective cation exchange capacity. Soils vary widely from slope to slope and the fertility status is determined by many factors according to the location such as vegetation and soil inherent properties. The upper slope compound farms had higher organic matter content, $\mathrm{CEC}$, and exchangeable $\mathrm{Ca}^{2+}$ than the LSCFs. The interaction of slope and management practices better influenced soil fertility properties than any single component. Proper management practices should therefore be adopted to improve soil fertility status of compound farms.

\section{References}

1. Ahn PM. "Tropical soils and fertilizer use". Longman and scientific-technical, U.K (1993): 207.

2. Aluko AP and Oguntala AB. "Fertility assessment of marginal land at Okoma forest reserve for conservation and management purposes”. Proc. 25th Annual Conference, Forestry Association Nigeria (1997): 13 -21.

3. Amuyou UA and Kotingo KE. "Top sequence analysis of soil properties of an agricultural field in the Obudu mountain slopes, Cross River State-Nigeria". European Journal of Physical and Agricultural Sciences 3.1 (2015): 2056-5879.

4. Asadu CLA and Akamigbo FOR. "The use of abrupt changes in selected soil properties to access lithological discontinuities in soils of Eastern Nigeria". Pedologie 37.1 (1987): 42-56.

5. Asadu CLA., et al. "A comparison of the contributions of clay, silt, and organic matter to the effective CEC of soils of sub-Saharan Africa". Soil Science 162 (1997): 785-794. 
6. Asadu CLA., et al. "Soil characteristics around Lake Opi in eastern Nigeria and land use recommendations". Agro Science Journal 2.1 (2001): 76-90.

7. Asadu CLA., et al. "Variations in Soil Physical Properties in a Cleared Forestland Continuously Cultivated for Seven Years in Eastern Nsukka, Nigeria”. Communications in Soil Science and Plant Analysis 41 (2010): 123-132.

8. Awdenegest M and Nicholas MH. "Soil Fertility in Relation to Slope Position and Agricultural Land Use: A Case Study of Umbulo Catchment in Southern Ethiopia”. Environmental management 42.5 (2008): 753-63.

9. Babalol TS., et al. "Relationship between soil properties and slope position in a humid forest of Southwest Nigeria". Agricultural. Journal 2 (2007): 370-374.

10. Bremner JM and Mulvaney CS. Total nitrogen. C.A Black, eds. Methods of Soil Analysis, part 2, Agronomy 9. American Society of Agronomy, Inc. Madison Wisconsin (1982): 1149-1178.

11. Bubba MO., et al. "Phosphorus adsorption maximum of sands for use as media in subsurface flow cultivated reed beds as measured by Langmuir isotherm". Water Research 37.14 (2003): 3390-3400.

12. Conway C. Results of the test run in the 96/97 raining season in the North Central Division. Ministry of Agriculture, Water and Rural Development, Namibia (1997): 40.

13. Enwenzor WO., et al. "Fertilizer use and management for crops in Nigeria". FPDD, Federal Ministry of Agriculture, Water Resources and Rural Development, Lagos, Nigeria (1989): 163.

14. Essiet EU. "A comparison of soil degradation under smallholder farming and large-scale irrigated land in Kano State, Northern Nigeria". Land Degradation and Rehabilitation 2 (1990): 209-214.

15. Essiet EU. "Agricultural sustainability under smallholder farming in Kano, Northern Nigeria". Journal of Arid Environment 48 (2001): 1-7.

16. Ezeaku PI. "Applicability of two concepts of land evaluation to the soils of southeastern Nigeria". Ph.D. Thesis. University of Nigeria Nsukka (2000): 271.

17. Ezeaku PI and Eze FU. "Effect of land use in relation to slope position on soil properties in a semi-humid Nsukka area, Southeastern Nigeria”. Journal of Agricultural Research 3 (2014): 52.

18. Ezeaku PI and Iwuanyanwu FC. "Degradation Rates of Soil Chemical Fertility as Influenced by Topography in Southeastern Nigeria". IOSR Journal of Environmental Science, Toxicology and Food Technology (IOSR-JESTFT) 6 (2013): 39-49.

19. Farmanullah K., et al. "Effect of slope position on Physico-chemical properties of eroded soil”. Soil Environ 32.1 (2013): 22-28.

20. Garcia A., et al. "Mineral nutrients in pasture herbage of central-western Spain. Soil, grassland and animal relationship". Proceedings of 13th general meeting of the European Grassland. Banska Bystrica. Czechoslovakia (1990): 25-29.

21. Gee GW and Or D. Particle size analysis. Methods of Soil Analysis. Dan, D. J., and Topps, G. C, eds. part 4, physical methods. Soil Science Society of America. Book series no. 5. ASA and SSSA Madison W.I (2002); 201-228.

22. Hendershot WH., et al. "Soil acidification along a topographic gradient on round top Mountain, Quebec, Canada". Water, Air, and Soil Pollution 61.3-4 (1992): 235-242.

23. Hossner LR and Juo ASR. "Soil nutrient management for sustained food crop production in upland farming systems in the tropics". Food and Fertilizer Technology Center (1999).

24. Jackson ML. Soil Chemical Analysis. New York: Prentice Hall Inc (1962): 498.

25. Kodiya HM. "Effects of irrigation on some soil characteristics in the south Chad irrigation project". M.Sc Thesis, Department of Geography, Bayero University, Kano (1998).

26. Landon JR. "Booker tropical soil manual, hand book for soil survey and agricultural land evaluation in Tropics and sub-tropics". Longman. New York (1991): 74.

27. Ludwig F., et al. "The Effect of nutrients and shade on tree-grass interactions on an East African savannah". Journal of vegetation science 12 (2001): 579-588.

28. Mbagwu JSC. "Saturated hydraulic conductivity in relation to the physical properties of soils in Nsukka plains, southeastern Ni- 
geria". Geoderma 68 (1995): 51-66.

29. McLean EO. Soil pH and lime requirement: Methods of Soil Analysis. Agronomy series 2nd Edition 9 (1982): $199-224$.

30. Mengel K and Kirkby EA. "Principles of plant nutrition". International Potash Institute. Worblanfen-Bern, Switzerland (1987).

31. Mulugeta D., et al. "Impact of slope position on soil carbon and total nitrogen stocks along a catena in Kindo Koye watershed, southern Ethiopia". Ethiopian Journal of Natural Resources 12.2 (2012): 185-195.

32. Nelson DW and Sommers LE. Total Carbon, Organic Carbon, and Matter. Page, A. L., Miller, R. H. and Kenney, D. R., (Eds), Methods of Soil Analysis, Chemical and Microbiological Properties, Part 2. Agronomy monograph 9 (1982).

33. Noma SS., et al. "Detailed soil survey of Sokoto - Rima floodplain at Sokoto, Nigeria". Managing oil resources for food security and sustainable environment Proc. 29th Annual Conference of Soil Science Society Nigeria (2005).

34. Ogunwale JA., et al. "Morphological, physico-chemical and clay mineralogical properties of soil overlying basement complex rocks in Ilorin East, Nigeria". Moor Journal of Agricultural Research 3.21 (2002): 147-164.

35. Ojanuga AG and Awojuola AI. "Characteristic and classification of the soils of the Jos plateau, Nigeria”. Nigeria Journal Soil Science 10 (1981): 101-119.

36. "Compound farms of southeastern Nigeria: A predominant agroforestry homegarden system with crops and small livestock". Agro forestry Systems, 5.153 (1987): 153-168.

37. Oko-Ibom GO and Asiegbu JE. "Growth and yield responses of rainy season field tomatoes to timing and splitting of fertilizer application". Journal of agriculture, food, environment and extension 5.1 (2006): 17-25.

38. Onyenweaku CE., et al. "Production relationships among compound and non-compound farms in Imo state, Nigeria". Journal of Applied Science in Southern Africa 2.1 (1996).

39. Olsen SR and Sommers LE. "Phosphorus. In: A. L. Page, R. H. Miller, and D. R Keeney, eds. Methods of soil analysis, Part 2, Chemical and Microbiological Properties". Madison, Wisconsin (1982): 403-430.

40. Rhoades JD. Cation Exchange Capacity. Methods of soil analysis. (Edited by Page, A. L., Miller, R. H. and Keeney, D. R.), American Society of Agronomy Inc., Madison, Wisconsin (1982): 149-157.

41. Ritter ME. "The physical Environment: An Introduction to Physical Geology”. Longman Group Limited, London (2006).

42. Soil Survey Staff (1999). Soil Taxonomy: A Basic System of Classification for making and interpreting soil surveys. N.R.C.S. USDA, Washinton DC (1999): 869.

43. Tanimu J., et al. "Effects of cow dung on the growth and development of maize crop". Greener Journal of Agricultural Sciences 3.5 (2013): 371-383.

44. University of Nigeria Meteorological Station (2010).

\section{Volume 2 Issue 1 January 2022}

(C) All rights are reserved by Benedict Odinaka Okorie., et al. 